\title{
An Analysis of Graduation Resources in Concession Addresses
}

\author{
Qi Li ${ }^{1}$, Guoqing $\mathbf{L i}^{2}$ \\ ${ }^{1}$ School of Foreign Languages, Guangzhou College of Commerce, Guangzhou, P. R. China \\ ${ }^{2}$ International College, Guangzhou College of Commerce, Guangzhou, P. R. China
}

Email address:

1805421124@qq.com (Qi Li), liguoqing020@126.com (Guoqing Li)

\section{To cite this article:}

Qi Li, Guoqing Li. An Analysis of Graduation Resources in Concession Addresses. International Journal of Language and Linguistics. Vol. 7, No. 3, 2019, pp. 102-109. doi: 10.11648/j.ijl1.20190703.12

Received: March 26, 2019; Accepted: May 8, 2019; Published: May 30, 2019

\begin{abstract}
The concession address is generally considered as the final swan song of a lost campaign, communicating the defeated presidential nominee's thankfulness and gratitude to his or her supporters. Transcripts, videos or audios of concession addresses are easily accessible to the public via internet, television or even radio. With its easy accessibility, the concession address plays a significant part and has a high profile in the public's daily life. Nonetheless, the researches on concession addresses are few and far between. Based on the system of Graduation within the Appraisal Theory, an analysis of graduation resources in concession addresses by American presidential nominees has been conducted. In this paper, the author aims to find how the political addresser to achieve alignment with the audience by using different kinds of graduation resources. The results show that American presidential nominees tend to be profusive in employing graduation resources, among which they are prone to employ far more Force resources than Focus resources in the given sample. This means that American presidential nominees are inclined to use force resources to highlight their attitudes and proper graduations, appropriately indicating their strong love to people and a strong sense of patriotism.
\end{abstract}

Keywords: Graduation, Force, Focus, Concession Address

\section{Introduction}

Political addresses are closely bound up with people's life. Among all kinds of public addresses, political addresses are characteristically unique and have always been a central concern of discourse analysis: many discourse analysts have conducted a great number of researches on various kinds of political addresses, such as campaign addresses, inaugural addresses, withdrawal addresses, farewell addresses, victory addresses, and so on. Nevertheless, compared with other kinds of political addresses, concession addresses, as an indispensable part of political addresses seem to be less attention-catching. Appraisal Theory is an expanded theorization of interpersonal meaning in language, featured by a comprehensive modeling of appraisal resources and a wide range of interpersonal strategies and details [1]. Appraisal Theory helps reveal writers/speakers' opinions and views towards the experiential world or events. In other words, Appraisal Theory interprets the evaluative meaning---the feeling of speaker/writer and their judgment and evaluation. Although many attempts have been made to apply Appraisal Theory into various political addresses, such as campaign addresses and inaugural addresses, the studies on concession addresses are relatively few. Appraisal Theory is mainly comprised of three systems: Attitude, Engagement and Graduation. Graduation plays a significant part in intensifying or weakening meanings [1]. This paper focuses on the system of Graduation regarding the degree of adjusting meaning. American concession addresses are chosen to be the research objects of the paper in that the voice of a winner from a presidential election usually attracts the attention from the pubic, subconsciously ignoring the voice of a defeated presidential nominee. As an essential part of political address, the concession address is rarely researched and it is of great value to conducting some researches on the concession address. 


\section{Literature Review}

\subsection{Previous Studies on Appraisal Theory}

Appraisal Theory originates from a project Write it Right from 1991 to 1994. Martin and his colleagues charged this project with the main focus on narrative discourse analysis and then the project gradually extended to various fields like literature works, history, and so on. As an important founder of Appraisal Theory, Martin (2000) is the first one to give a comprehensive introduction and systemic framework of Appraisal Theory [2]. In the following years, Appraisal Theory gets incessantly bettered. Martin \& Rose (2003) put forward a theoretical framework of systemic analysis of interpersonal meaning in their co-authored book [3]. Two years later, Martin \& White (2005) publish the book The Language of Evaluation: Appraisal in English, which has been the most detailed and mature version of Appraisal Theory so far [1].

Appraisal Theory has been applied to various areas of research. For example, Hood (2004) employs Appraisal Theory to investigate the difference of stance-taking between accomplished writers and student writers. In contrast to student writers use more personal and subjective Attitude resources (Affect and Judgment) to construe their texts, accomplished writers are inclined to use more Appreciation kind of Attitude resources to construe their texts as objectively as possible [4].

Martin \& Rose (2008) explain how appraisal resources in different genres function differently, for instance, appraisal resources in narrative genre play the function of organizing social relations, while in the historical genre appraisal resources play the function of interpretation [5]. White (2012) finds certain value positions must be attributed to others even in "hard news" which is widely acknowledged as objective [6]. Swain (2012) attempts to address a gap in the cartoon literature by applying Appraisal Theory to conduct an analysis of evaluative meanings in political cartoons [7]. Based on Appraisal Theory, Munday (2012) discusses how the translator deploys language to express his or her subjective interpretation and intervention in the translation. His corpus consists of 11 languages like French, Russian, Chinese and Japanese, becoming a relatively comprehensive and systemic attempt in Appraisal Theory's application into the field of translation [8].

In recent decades, an increasing number of Chinese scholars contribute a lot to the development of Appraisal Theory theoretically and practically.

Theoretically speaking, Wang (2001) gives a general account of Appraisal Theory in his paper "Appraisal system and its operation - the new development of Systemic Functional Linguistics". In this paper, he firstly briefs us the background and origin of Appraisal Theory. Then, he explains its theoretical framework and explores its application. Last, he gives a forecast of its development in the concluding part [9]. Wang \& Ma (2007) discuss the charm of Appraisal Theory and explain to us what dilemmas Appraisal Theory brings as well as how to get out of the dilemmas [10]. Zhu (2009) examines how speakers use implicit evaluation to convey their interpersonal meaning. He also discusses the significance and realization of implicit evaluation, which benefits a lot to the development of Appraisal Theory [11].

Practically speaking, Wang (2004) explores attitude resources in Chinese hard news and English hard news by employing the Attitude System, a significant subsystem of the Appraisal Theory. In this paper, he finds Judgment resources exceed Affect resources and Appreciation resources [12]. Liu (2010) applies Appraisal Theory into the field of Chinese-English translation. She compares two English versions of Dream of Red Mansions with the original work, aiming to reveal the faithfulness to the original text during the process of translation and find out the causes of unfaithfulness [13]. Xu (2011) applies Appraisal Theory into business translation practice to explore its feasibility and effectiveness [14].

\subsection{The Previous Studies on Political Addresses}

Generally speaking, political addresses can be divided into campaign addresses, inaugural addresses, farewell addresses, victory addresses, withdrawal address, concession addresses [15]. Many researches have been conducted in different kinds of political addresses, For example, in the analysis of campaign addresses, Li (2014) studies campaign address within cognitive linguistics. She adopts Framework Semantics Theory to discover the underlying reasons for the difference in Obama's two-term campaign addresses [16]. Zhang (2015) studies persuasive strategy in campaign address from the perspective of Prototype Theory and Categorization [17].

In the analysis of inaugural addresses, Barber (2002) does a good number of analyses of American presidential inaugural addresses, through which he finds the characters of presidents influenced the presidents' actions and views [18]. Xiong (2004) gives inaugural addresses a stylistic analysis, which boils down to lexicon, syntax, rhetoric and text [19]. Li (2006) analyzes inaugural address from the perspective of pragmatics. His study explores how positive politeness strategies are used in inaugural addresses to shorten the distance between the audience and the presidents [20]. Wang (2008) analyzes ten American inaugural addresses and five campaign addresses to find out the tactics of persuasion which are usually employed in political speeches. According to her analysis, rhetorical figures and rhetorical proofs are the two commonest tools of persuasion in political speeches [21]. Bira \& Mohammadi (2012) conduct a critical discourse analysis approach to investigate inaugural speeches, aiming to find out how political actors deploy language strategy to communicate political ideals [22].

Here are some major studies on other types of political addresses, such as withdrawal addresses, victory addresses and farewell addresses: in terms of withdrawal address, Sun \& Zhao (2012) study the intertextuality of withdrawal addresses to reveal the function and effect of alignment strategy [23]; in terms of victory address, Zhang (2014) compares Obama's victory addresses of two terms within the framework of 
Systemic Functional Grammar to explore how the president uses language to influence people's attitude towards things to achieve political purposes [24]; in terms of farewell address, Han (2016) conducts a positive discourse analysis on presidential farewell addresses on the basis of Appraisal Theory [25].

Apart from the researches on various genres of political addresses, many scholars are also keen on finding out how political addresses build intimacy or forge solidarity with the audience.

For example, Dedaić (2006) investigates how the rhetoric in political speeches can realize the interaction between the political orator and the audience. He believes political discourse is closely related to power and could create community and construct identity [26]. Kong (2013) tries to find the difference between effective leaders and ineffective leaders from the perspective of leader's rhetorical influence and contextual factors. After analyzing 30 American presidential outcomes, he finds in victory speech, there were much more positive terms than negative terms and much more action-oriented terms [27].

Martin (2015) regards addresses as the medium of ideas which influence political behaviors. He gives a rhetorical analysis to political strategy and shows how the rhetorical approach embodied in concrete examples [28]. Reyes (2015) explores how intimacy with the audience gets built by linguistic variables. He finds that strategical deployment of lexical selection and discourse structure helps weld intimacy with the audience [29].

Rossette (2017) analyzes the political oratory in four sampled political addresses from Barack Obama, Martin Luther King and Abraham Lincoln, aiming to explore how oratory helps construe discursive identities and shorten distance with the audience [30].

However, the studies on concession addresses (an essential kind of political address) how to forge solidarity with the audience are still deficient.

\section{Theoretical Framework}

Appraisal Theory consists of three subsystems: Attitude which involves human's feeling, Engagement which involves diversity of voices in discourse and Graduation which involves the degree of feelings [2]. Attitude construes human's feelings in terms of three fields which are Affect, Judgment and Appreciation. Engagement concerns itself with a dialogic positioning of the speaker/writer as well as the play of various voices in the text. Graduation attends to degrees to which feelings are strengthened or weakened [1]. A brief sketch of appraisal system is presented in Figure 1.

Attitude system reflects people's feelings, assessments and estimation [3].

Engagement system comprises two broad categories: Mono-glossia and Hetero-glossia. The former does not recognize other alternative stances or voices, while the latter acknowledges them. Heteroglossia is realized by two options: Dialogic Expansion (opening up dialogic space) and Dialogic
Contraction (closing down dialogic space) [1].

Graduation system is a scalable system which grades meaning in terms of Force and Focus. Force adjusts meaning in terms of intensity and quantity. Force either raises or lowers the meaning in light of intensity and quantity. Focus sharpens or softens the meaning in light of prototypicality [1].

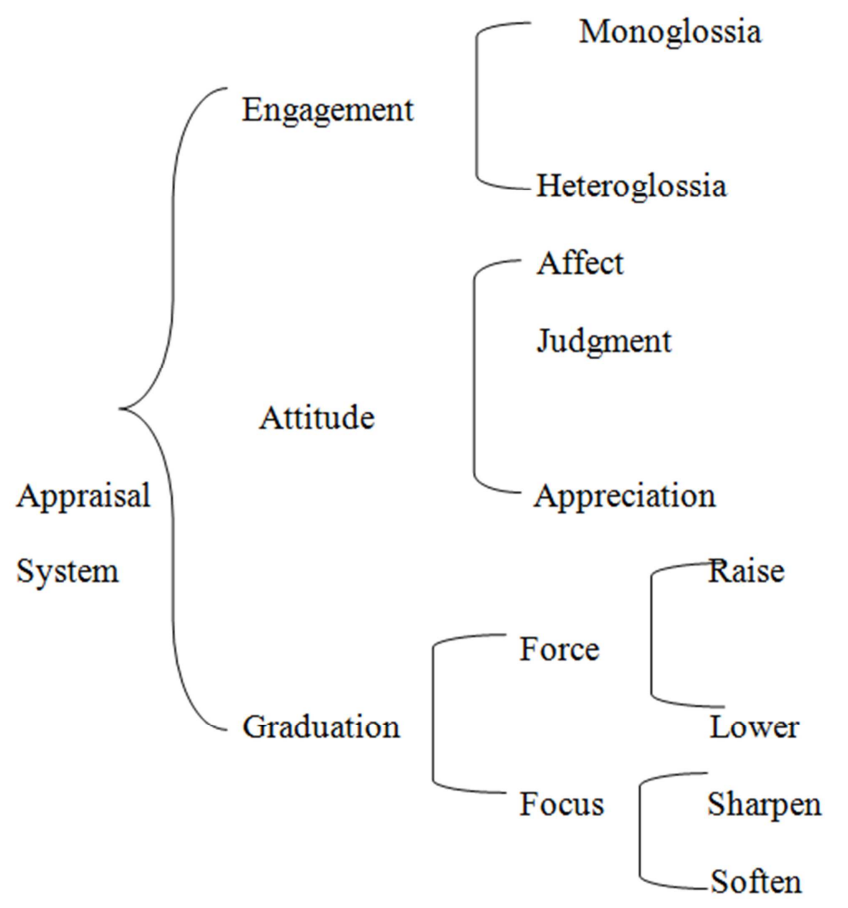

Figure 1. An Overview of Appraisal System (Martin \& White, 2005: 38).

Graduation System is comprised of two subdivisions, each of which has its own smaller sub-categories, which can be illustrated in Figure 2.

Grading meanings in terms of intensity and quantity, Force can "raise" or "lower" the degree of Attitude and Engagement resources [1]. There are two means of realizing Force. The first means is Intensification, which operates above quality (e. g. rather amusing, a little amusing) or over process (e. g. it is vastly undervalued, it is a bit undervalued). The second means is Quantification, which can be realized by Number (e. g. many setbacks, a few setbacks) or by Mass (e. g. a large cost, a small cost) or by Extent in time and space (e. g. an antiquated tray, a latest application, a far-off supermarket, a nearby supermarket)

Grading meaning in respect to prototypicality, Focus is applied to meanings which are usually seen as unscalable, redefining the most distinct categories not as a categorical proposition but a matter of degree [1]. Focus can be up-scale (termed as Sharpen) or down-scale (termed as Soften). Sharpen makes appraised object get closer to the prototype, typical remarks of which are true, real, genuine. Soften makes appraised object get further away from the prototype, typical remarks of which are of sorts, kind of.

Illustrated in the following examples, the first example sharpens the prototypicality and the second example softens the prototypicality.

Damon is a true soldier. (Sharpen) 
Damon is a soldier of sorts. (Soften)

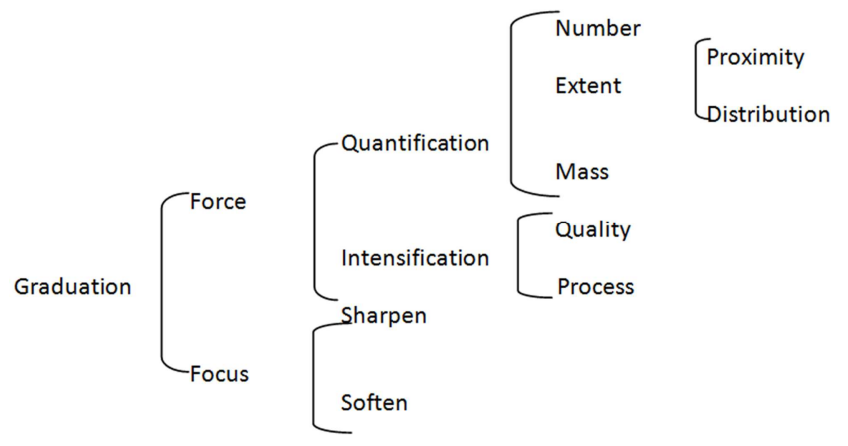

Figure 2. An overview of Graduation system (Martin \& White, 2005: 154).

\section{Research Design and Methodology}

This paper aims to reveal graduation resources in concession addresses by American presidential nominees. Frequencies and proportions of graduation resources will be calculated and analyzed to identify the appraisal patterns of concession addresses. Precisely speaking, this paper attempts to conduct an analysis of how appraisal resources are strategically deployed to forge solidarity with the audience. Research questions are listed as follows:

(1) What is the overall distribution of graduation resources in concession addresses?

(2) Why are the graduation resources so distributed in concession addresses?

(3) How do defeated American presidential nominees use different graduation resources to achieve alignment with the audience?

Five American concession addresses from 2000 to 2016 are selected as the corpus given that the transcripts of the concession addresses can be available online. The transcripts of the concession addresses of the failed presidential nominees are retrieved from official websites:

Al Gore's concession address of 2000 comes from the website

http://www.americanrhetoric.com/speeches/algore2000conce ssionspeech.html

John Kerry's concession address of 2004 comes from the website

http://www.washingtonpost.com/wp-dyn/articles/A22619-20

04Nov3.html

John McCain's concession address of 2008 comes from the website

https://www.npr.org/2017/07/22/538705462/john-mccains-20

08-concession-speech

Mitt Romney's concession address of 2012 comes from the website of

https://www.washingtonpost.com/politics/decision2012/mittromneys-concession-speech-full-transcript/2012/11/07/99f9c 98c-28a0-11e2-96b6-8e6a7524553f_story.html?noredirect $=\mathrm{O}$ n\&utm_term $=28 \mathrm{~d} 3 \mathrm{e} 6687 \mathrm{f} 87$

Hillary Clinton's concession address of 2016 comes from the website of http://time.com/4564480/read-hillary-clintons-concession-sp eech-full-transcript/

Moreover, the transcripts of the concession addresses are carefully checked with the video data on the Internet and filtered the interactive sessions between the failed presidential nominees and the audience. Since the election of United States of America catches attention around the globe, the concession addresses by American presidential nominees exert a worldwide influence. Therefore, the studies on concession addresses by American presidential nominees are well worthy of studying. In this thesis, the latest 5 concession addresses of American presidential nominees are selected here to analyze how those presidential nominees use appraisal resources to forge solidarity with the audience.

This paper adopts qualitative and quantitative analytical approaches to conduct an analysis of graduation resources in concession addresses. In the processing of the collected samples of concession addresses, the author strictly follows the below principles:

First, we will make a quantitative analysis on the data and calculate the distribution and frequency of different graduation resources in these concession addresses. Second, we will explore the similarities between them in the development of these graduation resources and appraisal strategies in concession addresses. Finally, we will reveal the common appraisal strategy of graduation used in concession addresses and common rules of concession addresses.

In order to facilitate a reliable examination of appraisal resources in concession addresses, tables and figures are used to display the result of analyses. When interpreting the results, the author should follow the below principles:

First, at least three perusals of these 5 sample concession addresses precede the labeling of graduation resources in them. The author will label the graduation resources twice and a third labeling will be made to examine the consistency of the data. By repeating these procedures, the author aims to minimize the careless errors which possibly occur between these labels.

Then, lists of showing the overall frequencies and percentage of graduation resources in concession addresses would be made.

Next, a detailed analysis of graduation resources is also conducted within the system of Graduation.

\section{Results and Discussion}

Table 1 presents overall distribution of graduation resources in concession addresses. As is indicated from Table 1, we can see all presidential nominees come to use graduation resources to varying degrees, but different kinds of graduation resources are distributed unevenly. Force resources take a predominant place in the total graduation resources, accounting for $98.01 \%$ with raise force accounting for $96.52 \%$ and lower force occupying $1.49 \%$. In contrast, Focus resources in concession addresses merely occupy an insignificant minority, making up only $1.99 \%$, less than $2 \%$. It should be noted that no soften focus resources appear in concession addresses. Furthermore, 
lower force resources also account for a low proportion with only total 3 occurrences and $1.49 \%$ proportion. Henceforth, it can be deduced that the down-scale graduation resources (lower force resources and soften focus resources) make up negligible amount.

Table 1. Distribution of Graduation Resources.

\begin{tabular}{llllll}
\hline Graduation Resources & Force & \multicolumn{3}{l}{ Focus } & \multirow{2}{*}{ sum } \\
\cline { 1 - 4 } Presidential Nominees & Raise & Lower & Sharpen & Soften & \\
\hline Gore & 31 & 0 & 1 & 0 & 32 \\
Kerry & 43 & 3 & 2 & 0 & 48 \\
McCain & 44 & 0 & 0 & 0 & 44 \\
Romney & 15 & 0 & 0 & 0 & 15 \\
Hillary & 61 & 0 & 1 & 0 & 62 \\
Total Number & 194 & 3 & 4 & 0 & 201 \\
Total Percent & $96.52 \%$ & $1.49 \%$ & $1.99 \%$ & 0 & $100 \%$ \\
\hline
\end{tabular}

\subsection{Realization of Force in Concession Addresses}

Force realization can be achieved by Intensification and Quantification. From Table 2, we can see the detailed distribution of force resources:

Table 2. Detailed Distribution of Force Resources.

\begin{tabular}{|c|c|c|c|c|}
\hline \multirow{2}{*}{\multicolumn{2}{|c|}{$\begin{array}{l}\text { Presidential } \\
\text { Nominees }\end{array}$}} & \multicolumn{2}{|l|}{ Force } & \multirow{2}{*}{ Sum } \\
\hline & & Intensification & Quantification & \\
\hline \multirow[t]{3}{*}{ Gore } & Raise & 18 & 13 & \multirow{2}{*}{31} \\
\hline & Lower & 0 & 0 & \\
\hline & Percentage & $58.06 \%$ & $41.94 \%$ & $100 \%$ \\
\hline \multirow[t]{3}{*}{ Kerry } & Raise & 11 & 32 & \multirow{2}{*}{46} \\
\hline & Lower & 3 & 0 & \\
\hline & Percentage & $30.43 \%$ & $69.57 \%$ & $100 \%$ \\
\hline \multirow[t]{3}{*}{ McCain } & Raise & 23 & 21 & \multirow{2}{*}{44} \\
\hline & Lower & 0 & 0 & \\
\hline & Percentage & $52.27 \%$ & $47.73 \%$ & $100 \%$ \\
\hline \multirow[t]{3}{*}{ Romney } & Raise & 7 & 8 & \multirow{2}{*}{15} \\
\hline & Lower & 0 & 0 & \\
\hline & Percentage & $46.67 \%$ & 53.335 & $100 \%$ \\
\hline \multirow[t]{3}{*}{ Hillary } & Raise & 26 & 35 & \multirow{2}{*}{61} \\
\hline & Lower & 0 & 0 & \\
\hline & Percentage & $42.62 \%$ & $57.38 \%$ & $100 \%$ \\
\hline
\end{tabular}

Quantification

Quantification can be realized by three options:

The first option is Number which modifies quantity either by accurate numbers or by inaccurate numbers [1]. See following concrete examples:

Example 1:

There's so much [Number, Quantification, Raise] written about campaigns, and there's so much [Number, Quantification, Raise] that Americans never get to see. (Kerry's address)

In Example 1, the number of descriptions about the campaign is upscaled twice with "so much". Kerry repeats the expression "so much" (inaccurate number) to exaggerate the quantity about the campaign, thus raising force.

Example 2:

And I pledge to him tonight to do all in my power to help him lead us through the many [Number, Quantification, Raise] challenges we face. (McCain's address)

In Example 2, the abstract quantified entity challenge is modified by the Number "many". Attitudinal meanings usually find their expression in these abstract entities (Martin \&White, 2005:149). In this example, many challenges express the attitudinal meaning of Appreciation. Using "many" can upscale the number of challenge and raise the quantification force.

The second option is Mass which describes the physical or abstract size of things. See concrete example of Mass.

Example 3:

To Barack and Michelle Obama, our country owes you an enormous [Mass, Quantification, Raise] debt of gratitude. (Hillary's address)

In Example 3, the gratitude owed to Barack and Michelle Obama is upscaled in Mass to "enormous". Barack Obama once implored America to choose Hillary Clinton and painted Donald Trump as unfit to lead America. Evidently, Barack and Michelle Obama are in huge favor of Hillary Clinton. In this here-and-now discourse, Hillary uses the collective noun "our country" to implicate audience to show gratitude to the former president and his wife.

Example 4:

President-elect Bush inherits a nation whose citizens will be ready to assist him in the conduct of his large [Mass, Quantification, Raise] responsibilities. (Gore's address)

In Example 4, the American presidential responsibilities are upscaled in Mass to "large responsibilities" to indicate to be an American president can be very high-demanding, which requires conscientiousness and painstakingness.

The third option is Extent which modifies quantity in accordance with Time and Space. See concrete example of Extent.

Example 5:

Other disputes have dragged on for weeks [Distribution, Time, Raise] before reaching resolution. (Gore's address)

In Example 5, for weeks acts an up-scale modifier of the graduated entity (other disputes) to raise the distribution of time (the extended time). Combined with the verb "drag on" meaning to proceed for an extended period of time, Gore creates the audience an impression that the disputes have been carried on for a long time.

Example 6:

America always [Distribution, Time, Raise] moves forward. (Kerry's address)

In Example 6, Kerry attempts to build intimacy with the audience by commending the shared country--America. The promising future of United States is upscaled in distribution of time to "always".

Example 7:

to every last volunteer who fought so hard and valiantly, month after month, [Distribution, Time, Raise] in what at times seemed to be the most challenged campaign in modern times, thank you so much. (McCain's address)

In Example 7, the endurance time of fight for campaign is upscaled in distribution of time to "month after month", upscaling of the tenacity of his campaign staff.

Intensification

There are two modes of Intensification: intensification of 
Process which usually modifies verbs and intensification of Quality which usually modifies adjectives. Both intensification of Process and intensification of Quality can be upscaled or downscaled.

See concrete examples of intensification:

Example 1:

I'm sorry that we got here a little bit [Process, Intensification, Lower] late and a little bit [Process, Intensification, Lower] short. (Kerry's address)

Example 2:

You may not understand completely [Process, Intensification, Lower] in what ways, but it is true when I say to you that you have taught me and you've tested me and you've lifted me up and you've made me stronger. (Kerry's address)

In Example 1, late and short are downscaled with "a little bit" to put his defeat in a mild tone. In example 2, the mental process understand is downscaled by "may not completely" to indicate that the audience do not have a full understanding.

Example 3:

I particularly [Process, Intensification, Raise] urge all who stood with us to unite behind our next president. (Gore's address)

Example 4:

I do [Process, Intensification, Raise] have one regret: that I didn't get the chance to stay and fight for the American people over the next four years. (Gore's address)

Examples 3 and 4 clarify how verbal process gets upscaled. In example 3, the verbal process "I urge" is upscaled by the adverbial "particularly" to raise the force of "urge", indirectly indicating the Gore is so magnanimous as to discard his personal grievances to unconditionally support the new president (the former opponent). In example 4, Gore upscales his regret through "I do have one regret", strengthening his regretful feeling.

Example 5:

I am so deeply [Quality, Intensification, Raise] grateful to all of you for the great honor of your support and for all you have done for me. (McCain's address)

Example 6:

I'm incredibly [Quality, Intensification, Raise] honored and grateful to have had this chance to represent all of you in this consequential election. (Hillary's address)

In Examples 5 and 6, the positive emotions of presidential nominees are upscaled in quality "so deeply grateful" and "incredibly honored" to strengthen the positive emotions of presidential nominees.

Repetition can also realize intensification by repeating a word or an idea in different words ${ }^{[1]}$. Repetition can cut across both intensification of Quality and intensification of Process. See concrete examples of Repetition:

Example 1:

I don't know -- I don't know [Repetition: Force] what more we could have done to try to win this election. (McCain's address)

In example 1, McCain repeats the sentence "I don't know" to convey a sense of regret. In this instance, repetition does raise the force of attitude of the presidential nominee in that McCain seemingly shows his helplessness in this election, while he actually communicates a kind of regretful feeling to the audience.

Example 2:

I so wish-I so wish [Repetition: Force] that I had been able to fulfill your hopes to lead the country in a different direction. (Romney's address)

In Example 2, Romney repeats his desiring by the sentence "I so wish" (two times) to convey his aspiration to materialize the public's hopes and lead the country in a different direction.

Example 3:

It is natural. It's natural, [Repetition: Force] tonight, to feel some disappointment. (McCain's address)

In Example 3, McCain repeats the sentence "It is natural" to show that the audience has every reason to feel disappointed, subconsciously weld the solidarity with audience by assuming the audience feels likewise.

Example 4:

This loss hurts, but please never stop believing that fighting for what's right is worth it. It is. It is worth it [Repetition: Force] (Hillary's address)

In Example 4, rather than expressing negative feeling, Hillary stresses that fighting for what is right is of great value though the loss may hurt. She attempts to inform the audience that everyone may undergo distress or agony but we should never ever stop fighting for what we believe in.

Example 5:

Let there be no doubt, while I strongly disagree with the court's decision, I accept it. I accept [Repetition: Force] the finality of this outcome which will be ratified next Monday in the Electoral College. (Gore's address)

In Example 5, Gore repeats the sentence "I accept it" two times to demonstrate his reconciliation to the final loss, indirectly showing his making peace with the final outcome.

\subsection{Realization of Focus in Concession Addresses}

Focus adjusts meaning in light of prototypicality, adjusting attitudinal assessments by Sharpening and Softening [3]. In concession addresses, presidential nominees tend to cement a strong relationship between the audience by adjusting the strength of boundaries. See concrete examples of Focus:

Example 1:

Sometimes really [Focus: Sharpen] painful ones (Hillary's address)

In Example 1, Hillary adopts the Sharpen focus resource "really" to emphasize the painfulness of the setbacks that she had been through.

Example 2:

with gratitude to our truly [Focus: Sharpen] tireless campaign staff and volunteers. (Gore's address)

In Example 2, Gore expresses his positive judgments of social esteem on his campaign staff and volunteers by employing Sharpen focus resource "truly". As mentioned above, Sharpening generally implies a positive attitudinal assessment. In this example, Gore uses the sharpening expression "truly" to manifest his highly positive judgment of 
his campaign staff and volunteers, strongly aligning the audience into the value stance.

Example 3:

but we stood for real [Focus: Sharpen] change, change that would make a real [Focus: Sharpen] difference in the life of our nation and the lives of our families. (Kerry's address)

In this example, Kerry uses "real" to sharpen the prototypicality of change and difference to convey a positive message, cementing a strong relationship between the audience by adjusting the strength of boundaries.

\section{Conclusion}

As an indispensable component of political addresses, concession addresses attract much less attention than other kinds of political addresses. Therefore, an analysis of appraisal resources in concession addresses contributes to the development of Appraisal Theory and brings a new perspective to the linguistic research on Concession Addresses This study hopefully sheds light on the intersubjectivity in concession addresses through analyzing appraisal resources. This study attempts to reveal appraisal resources in concession addresses, trying to explore how appraisal resources of concession addresses deployed to forge solidarity with the audience.

The winners of presidential election always draw much attention from the world and their speeches, like presidential inaugural address has always been a hot study topic of linguistics. Nevertheless, the losers of presidential election are always neglected by the world and the study on concession address is rather rare. Exploring how appraisal resources in concession addresses are employed to forge solidarity with the audience, this study is conducive to the accomplishment of social reconciliation and social harmony. To be specific, this study can alleviate the confrontation between the people who support the presidential winner and the people who support the presidential loser in the presidential campaign.

In concession addresses, defeated American presidential nominees are inclined to deploy many a graduation resource to convey interpersonal meaning in concession addresses. Compared with Focus resources, there are much more Force resources in the given sample. Occupying 98.01\% of all graduation resources, Force resources are almost 50 times as much as Focus resources which only make up 1.99\%. Moreover, the proportion of the Raise force outweighs the Lower force in the selected concession addresses, with Raise force occupying $96.53 \%$ whereas Lower force accounting for $1.49 \%$. This means presidential nominees are inclined to use Raise force resources to highlight their strong attitudes and proper engagements, appropriately indicating their love to people and country. Presidential nominees strengthen or weaken their attitudes by these graduation resources.

This paper analyzes 5 concession addresses delivered by U. S. presidential nominees. Based on an analysis on appraisal resources in the selected samples, the author analyzes how failed presidential nominees use different graduation resources to forge solidarity with the audience. The results of the paper leave much to be desired in the study of concession addresses and more improvements need to be done though some findings have been found out in the paper. First is the limitation of data corpus. In this study, merely 5 concession addresses were selected to analyze and the number of this kind of concession address is slightly inadequate. Second is the subjectiveness. Although an objective analysis has been intended to be secured, the subjectiveness is far from being avoided completely.

\section{References}

[1] Martin, J. R. \& White, P. R. R. (2005). The Language of Evaluation: Appraisal in English. New York: Palgrave Macmillan Ltd.

[2] Martin, J. R. (2000). Beyond Exchange: Appraisal Systems in English. In S. Hunston \& G. Thompson (eds.), Evaluation in Text: Authorial Stance and the Conversation of Discourse. Oxford: Oxford University Press.

[3] Martin, J. R. \& Rose, D. (2003). Working with Discourse: Meaning Beyond the Clauses. London \& New York: Continuum.

[4] Hood, S. (2004). Appraisal Research: Taking a Stance in Academic Writing. University of Technology Sydney.

[5] Martin, J. R. \& Rose, D. (2008). Genre Relations: Mapping Culture. London: Equinox.

[6] White, P. R. R. (2012). Exploring the Axiological Workings of 'Reporter Voice' News Stories-Attribution and Attitudinal Positioning. Discourse Context \& Media, 1(2-3), 57-67.

[7] Swain, E. (2012). Analysing Evaluation in Political Cartoons. Discourse Context \& Media, 1, 82-94.

[8] Munday, J. (2012). Evaluation in Translation: Critical Points of Translator Decision-making. London: Routledge.

[9] Wang, Z. H. (2001). Appraisal Systems and Their Operation: A New Development in the Systemic Functional Linguistics. Foreign Languages, (6), 13-20.

[10] Wang, Z. H. \& Ma, Y. L. (2007). Appraisal Theory: Charm and Dilemma. Foreign Language Education, 28(6), 19-23.

[11] Zhu, Y. S. (2009). Implicit Evaluation of Ideational Meaning. Foreign Language Education, 30(4), 1-5.

[12] Wang, Z. H. (2004). An Appraisal Approach to Hard News in Both English and Chinese-Appraisal Systems Inquiry (II). Foreign Language Education, (5): 30-31

[13] Liu, X. L. (2010). Translation Study: An Appraisal Perspective - A Case on Comparative Study of Two English Versions of Hong Lou Meng. Foreign Languages Research, 2010(3), 161-163.

[14] Xu, J. (2011). A Study of Business Translation from the Perspective of Appraisal Theory. Journal of PLA University of Foreign Languages, 34(6), 88-91.

[15] Zhang, J. T. (1999). Classification and Language Requirement of Speeches. Journal of Shenyang Normal University (Social Science Edition), (01), 63-65. 
[16] Li, M. J. (2014). A Comparative of Obama's Two-term Presidential Campaign Speeches from the Perspective of Frame Semantics. Hunan Normal University.

[17] Zhang, X. Y. (2015). On the Strategy of persuasion in Hillary Clinton's Campaign Speech from the Perspective of Prototype Theory and Categorization. Foreign Languages Research, (5), $1-5$.

[18] Barber, J. (2002). Presidential Character: Predicting Performance in the White House. London: Prentice-Hall.

[19] Xiong, L. (2004). A Stylistic Study of American Presidential Inaugural Address. Huazhong Normal University.

[20] Li, L. W. (2006). A Pragmatic Analysis of Positive Politeness Strategy in American Presidential Inaugural Addresses. Hebei Normal University.

[21] Wang, L. (2008). A Rhetoric of Persuasion in English Political Speeches. Zhengzhou University.

[22] Biria, R. \& Mohammadi, A. (2012). The Socio Pragmatic Functions of Inaugural Speech: A Critical Discourse Analysis Approach. Journal of Pragmatics, 44(10):1290-1302.

[23] Sun, Y. \& Zhang, W. J. (2012). An Analysis of Hillary Clinton's Withdrawal Speech Strategy from the Perspective of Intertextuality. Journal of Ningxia University (Humanities \& Social Sciences Edition)), 34(5), 193-196.
[24] Zhang, G. C. (2014). A Contrastive Study of Barack Obama's Victory Speech of 2008 and 2012: A Systemic Functional Approach. Inner Mongolia University.

[25] Han, J. (2016). Positive Discourse Analysis of Farewell Addresses. Changchun University of Science and Technology.

[26] Dedaić, M. N. (2006). Political Speeches and Persuasive Argumentation. Encyclopedia of Language \& Linguistics, 10(2), 700-707.

[27] Kong, D. T. (2013). Leader Election Outcomes as Contextual Moderators Explaining the Different Frequencies of Action-oriented Terms and Negation Terms Used in Inaugural Speeches of Effective Versus Ineffective Leaders and Charismatic Versus Non-Charismatic Leaders: Evidence from 30 U. S. Presidents. Personality \& Individual Differences, 55(7), $760-765$

[28] Martin, J. (2015). Situating Speech: A Rhetorical Approach to Political Strategy. Political Studies, 63(1), 25-42.

[29] Reyes, A. (2015). Building Intimacy through Linguistic Choices, Text Structure and Voices in Political Discourse. Language \& Communication, 43, 58-71.

[30] Rossette, F. (2017). Discursive Divides and Rhetorical Staging, or the Transcending Function of Oratory. Journal of Pragmatics, $108,48-59$. 